\title{
COMPATIBILITY OF TERNE SHEET WITH PALM BIODIESEL BLENDS
}

\section{CHEE LIANG YUNG*; NURSYAIRAH JALIL*; MASANOBU MIYAMOTO**; SHUNJI SAKAMOTO**; KAZUSHI MARUYAMA**; SOH KHEANG LOH* and WENG SOON LIM*}

\begin{abstract}
The quality of biodiesel blends and its compatibility with fuel tank materials needs to be investigated before any higher biodiesel blends are introduced. This is to ensure that there are no leaching of any undesired materials which may degrade or oxidise the fuel and ultimately cause failure to vehicles. This article discusses the oxidation stability of palm biodiesel and its blends with petroleum diesel, i.e. B7, B10 and B15. The effect of palm biodiesel and its blends on terne sheet were examined using cup test. Terne sheet, a material commonly used to fabricate automotive fuel tanks, has been previously identified as incompatible with biodiesel. Nevertheless, the findings showed that palm biodiesel blends would not cause any corrosion or incompatibility with terne sheet. The terne plating was maintained at approximately $40 \mathrm{~g} \mathrm{~m}^{-2}$ after exposure to palm biodiesel and its blends at $80^{\circ} \mathrm{C}$ for $1000 \mathrm{hr}$. Scanning electron microscopy (SEM) morphologies have shown no signs of corrosion or pitting on the surface of the terne plating. No leaching of heavy metals was found on the fuel samples. Hence, the terne sheet was found compatible with palm biodiesel blends as long as the test fuels in use were of good quality.
\end{abstract}

\section{Keywords: material compatibility, oxidation stability, palm biodiesel, terne sheet.}

Date received: 2 March 2018; Sent for revision: 2 March 2018; Received in final form: 5 Jun 2018; Accepted: 16 November 2018

\section{INTRODUCTION}

Biodiesel is defined as a fuel comprised of monoalkyl esters of long chain fatty acids (ASTM International, 2015). It can be derived from either vegetable oils or animal fats. Biodiesel is a product of transesterification process in which the said feedstocks are reacted with methanol in the presence of a base catalyst (Clark et al., 1984; Ali et al., 1995; Choo et al., 1995; Chang et al., 1996; Cvengros et al., 1999; Mittelbach and Enzelsberger, 1999). The raw materials used for the production of biodiesel vary dependant on locations. Soyabean oil is typically

\footnotetext{
* Malaysian Palm Oil Board,

6 Persiaran Institusi, Bandar Baru Bangi,

43000 Kajang, Selangor, Malaysia.

E-mail: clyung@mpob.gov.my

** Nippon Steel \& Sumikin Technology Co. Ltd

Yawata Unit, 2-1 Tobihatamachi, Tobata-ku,

Kitakyushu City, Fukuoka 804-0001, Japan.
}

used in the United States and Argentina, whereas rapeseed oil is common in the European continent. In South-east Asia, palm oil is the most widely used oil (Kushairi et at., 2017).

Biodiesel is designated as B100 whereas its blends with petroleum diesel are designated as $\mathrm{BX}$, where $\mathrm{X}$ is the vol\% of biodiesel in petroleum diesel (ASTM International, 2015). Biodiesel blends have been commercially used in many countries for more than a decade. The biodiesel programme with $<7 \%$ biodiesel $(\mathrm{B}<7)$ was implemented in Europe particularly in Germany, France, United Kingdom, the Netherlands, etc. In the United States, the biodiesel blends, i.e. B5, B10 and B20 were supplied to retail stations on a voluntary basis (Tang et al., 2008; Guzman et al., 2010; Alleman et al., 2011). In South-east Asia, Indonesia mandated to use B20 while Malaysia and Thailand B7 and B5 in the Philippines. The B5 blend was first introduced to retail stations in different regions of Peninsular 
Malaysia in stages since mid-2011 (Yung et al., 2016). In November 2014, the B5 was replaced by B7. The B7 programme was further expanded to Sabah and Sarawak in December 2014. This marked the nationwide B7 implementation in the country.

The use of higher biodiesel blends ( $>7 \mathrm{vol} \%)$ is of great concern because of the stability and compatibility with the engine or fuel tank materials. Various studies have been conducted showing both positive and negative effects of biodiesel (pure form and blended) on various metallic components. The results were summarised in Table 1.

Tsuchiya et al. (2006) studied the corrosion effect of biodiesel blends (B0-B5) using the cup test method. They discovered that B2 corroded the terne cup specimen and the corrosion was due to the formation of short chain organic acids in the degraded biodiesel blends. In the fuel circulation test, the fuel tank which was exposed to biodiesel blends with sufficient oxidation stability, i.e. $9.6 \mathrm{hr}$ Rancimat induction period (IP) was found corrosion free. The plating residual quantity of fuel tank made of terne sheet remained at about $40 \mathrm{~g} \mathrm{~m}^{-2}$. It was concluded that three important parameters of biodiesel blends, i.e. oxidation stability, acid number (AN) and organic acids concentration would determine the corrosion of metallic materials. They concluded the limit of (1) AN of $0.13 \mathrm{mg} \mathrm{KOH} \mathrm{g}^{-1}$ (max) and (2) total organic acids concentration of 30 ppm (max) must be regulated to prevent corrosion on metal components, in particular, the fuel tank.

Kaul et al. (2007) conducted the static immersion test for piston metal and piston liner at an ambient temperature that ranged from $15^{\circ} \mathrm{C}$ to $40^{\circ} \mathrm{C}$ for 300 days. The study showed no corrosion to the piston metal and piston liner for Mahua and Karanja biodiesels, but vice versa for Salvadora biodiesel possibly due to a much higher sulphur content of 1200 ppm. The Jatropha biodiesel showed slight effects on the piston liner. All four types of biodiesel degraded significantly after the test. There was a drastic change of AN from $0.4 \mathrm{mg} \mathrm{KOH} \mathrm{g}^{-1}$ to $11-$ $19 \mathrm{mg} \mathrm{KOH} \mathrm{g}^{-1}$ for Jatropha, Mahua and Karanja biodiesel, while that of Salvadora biodiesel increased from $0.45 \mathrm{mg} \mathrm{KOH} \mathrm{g}^{-1}$ to $2.3-2.5 \mathrm{mg} \mathrm{KOH} \mathrm{g}^{-1}$.

Haseeb et al. (2010) studied the corrosion behaviour of petroleum diesel and palm biodiesel on coupons made of copper and leaded bronze. The corrosion rates in copper were found higher than in leaded bronze at room temperature $\left(25^{\circ} \mathrm{C}-30^{\circ} \mathrm{C}\right)$ and $60^{\circ} \mathrm{C}$. The corrosion rates were higher at $60^{\circ} \mathrm{C}$ compared to room temperature. The AN of palm biodiesel had doubled to $1 \mathrm{mg} \mathrm{KOH} \mathrm{g}{ }^{-1}$ upon storage at room temperature for $2640 \mathrm{hr}$. However, no significant changes in $\mathrm{AN}$ were observed for petroleum diesel.

Fazal et al. (2010; 2011a, b; 2012) carried out studies on the corrosive effects of palm biodiesel and petroleum diesel on various metallic coupons including copper, aluminium, stainless steel, cast iron, mild steel and brass. Copper and aluminium were found susceptible to corrosion by both the palm biodiesel and petroleum diesel, and were detected in the fuels upon storage at $80^{\circ} \mathrm{C}$ for 1200 hr (Fazal et al., 2010). However, stainless steel was found free from corrosion. Significant pits were observed on the scanning electron microscopy (SEM) images of copper specimens. The AN of palm biodiesel exposed to these specimens increased four-fold from 0.35 to $>1.5 \mathrm{mg} \mathrm{KOH} \mathrm{g}^{-1}$, even for stainless steel which was found to be compatible with biodiesel. Although tertbutyl amine can be an effective corrosion inhibitor for palm biodiesel, it has no effect on the AN of the biodiesel samples exposed to cast iron at room temperature for 1200 $\mathrm{hr}$ as the value has doubled to $1 \mathrm{mg} \mathrm{KOH} \mathrm{g}^{-1}$ (Fazal et al., 2011a). Similar to copper and leaded bronze, the corrosion rate on mild steel increased at elevated temperatures of $50^{\circ} \mathrm{C}$ and $80^{\circ} \mathrm{C}$ (Fazal et al., 2011b). The AN of palm biodiesel exposed to mild steel has increased to $2 \mathrm{mg} \mathrm{KOH} \mathrm{g}^{-1}$ upon storage at the elevated temperatures for $1200 \mathrm{hr}$. Interestingly, the AN of palm biodiesel stored at $80^{\circ} \mathrm{C}$ even without mild steel exposure has also increased to $1.5 \mathrm{mg}$ $\mathrm{KOH} \mathrm{g}{ }^{-1}$. This suggested that the degradation of palm biodiesel was accelerated by both the elevated temperature and the presence of mild steel. The copper and brass corrosion rates were higher compared to aluminium and cast iron (Fazal et al., 2012).

$\mathrm{Hu}$ et al. (2012) examined metals exposure to rapeseed biodiesel at $43^{\circ} \mathrm{C}$ for 60 days. They found the copper and mild carbon steel exhibited more significant corrosion effects than aluminium and stainless steel. The atomic absorption spectrometry results showed the increase of copper and iron concentrations for the biodiesel exposed to copper, mild carbon steel and stainless steel, respectively.

Japan Petroleum Energy Centre (JPEC) (2012) investigated the material compatibility of soyabean oil biodiesel on various materials using similar cup test approach as demonstrated by Tsuchiya et al. (2006). The materials studied including terne sheet, bonderised steel, tin galvanised steel sheet and hotdipped aluminium-coated steel sheet. Pitting was observed on the surfaces of terne test cups exposed to biodiesel. Lead was detected in B20, B50 and B100 at the end of the test. This indicated elution of terne plating from steel sheet to the tested fuels.

Kovacs et al. (2015) evaluated the storage and corrosion characteristic of biodiesel sampled from an operational tank dedicated for automotive fuel blending facility in Hungary. The biodiesel sample met key properties stipulated in the European Standard EN 14214 with Rancimat IP $>6$ hr. The corrosion tests performed revealed that although the AN of biodiesel samples exposed to carbon steel coupons at $35^{\circ} \mathrm{C}$ for 120 days had slightly 


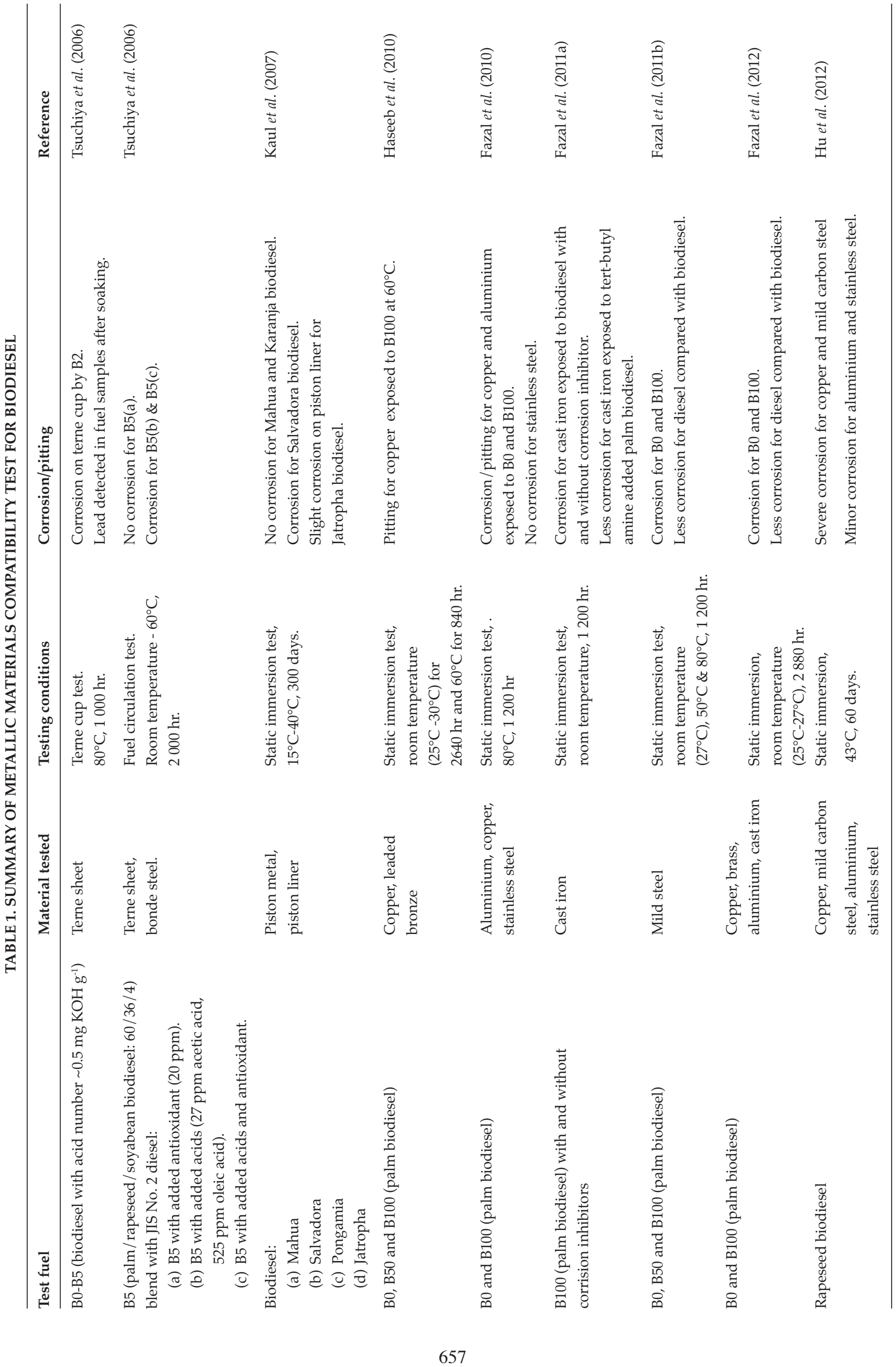




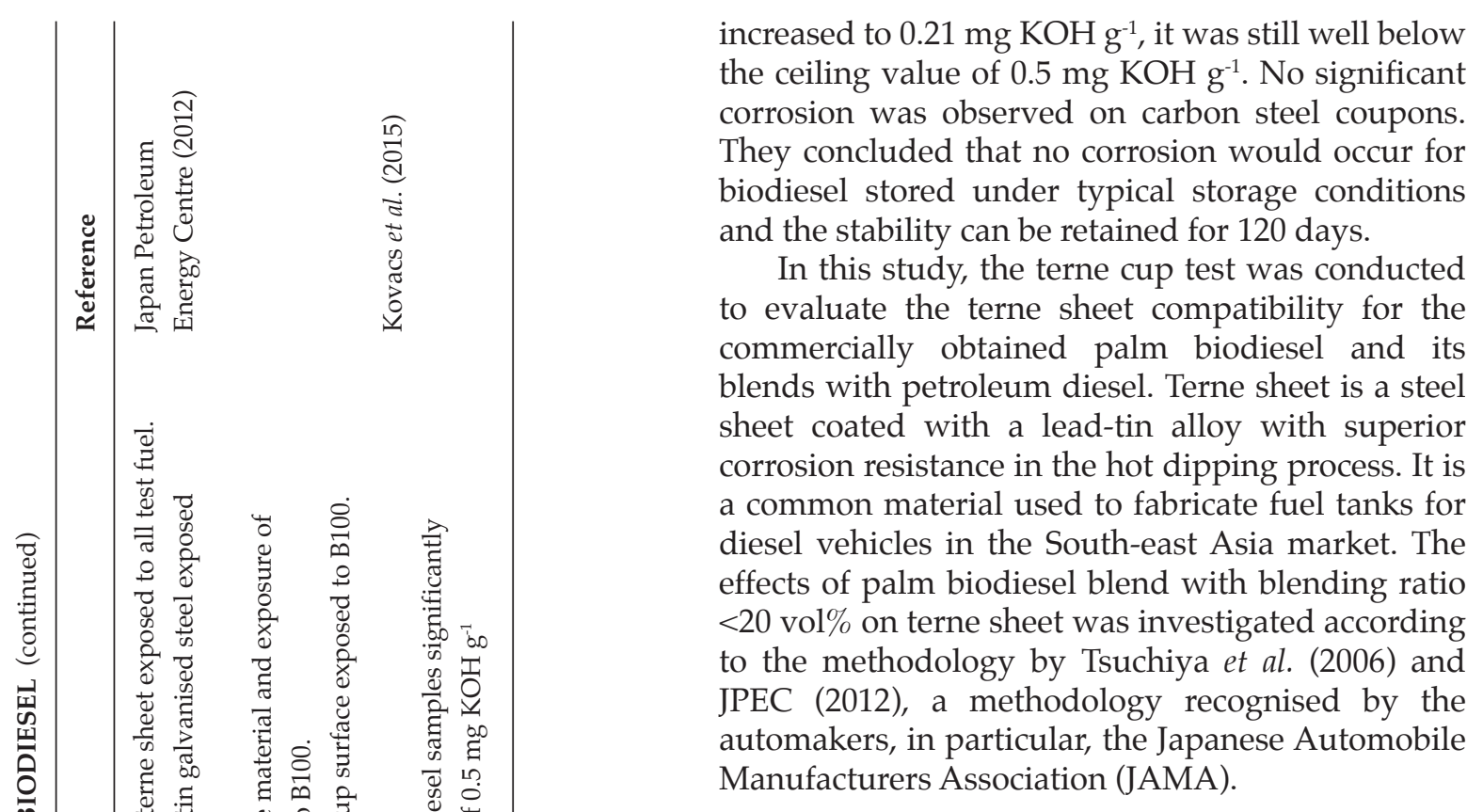

MATERIALS AND METHODS

\section{Materials}

Two types of petroleum diesel (Euro 2M and Euro 5) were obtained from Malaysian diesel suppliers. Palm biodiesel was obtained locally from a palm biodiesel producer. Both the petroleum diesel and palm biodiesel complied fully with the relevant local diesel (MS123-1:2014, MS123-3:2016) and biodiesel (MS2008:2014) standard specifications respectively (Department of Standards Malaysia, 2014a, b; 2016). Test cups made of terne sheet with a dimension of $50 \mathrm{~mm}$ internal diameter and $35 \mathrm{~mm}$ depth were used in this study.

\section{Methods}

The biodiesel blends (B7, B10 and B15) were prepared by blending palm biodiesel with petroleum diesel according to the stated vol $\%$. The fuel samples were analysed for oxidation stability using both the Rancimat (EN 15751) and the PetroOXY (ASTM D7545) methods.

Material compatibility study was conducted using test cups made of terne sheet. The $40 \mathrm{ml}$ of each fuel sample was filled into a test cup. The test cups were sealed with glass covers and tightened with clamps, then stored at $80^{\circ} \mathrm{C}$ for $1000 \mathrm{hr}$. The tested fuel samples were exchanged with fresh samples every $250 \mathrm{hr}$. The test was triplicated for every fuel sample. The appearances of the cups were examined and photographs were taken during every change of the fuel samples.

The heated fuel samples were analysed for organic acids content, metal contents and AN. Organic acids content was determined using a 
Dionex Ion Chromatograph ICS-90 equipped with an IonPac ICE-AS1 column (9 $\mathrm{mm}$ x $250 \mathrm{~mm}$ ) according to JIS $\mathrm{K} 0127$. The eluent was $1.0 \mathrm{mmol}$ litre $^{-1}$ octane sulphonic acid with a flow rate of 1.0

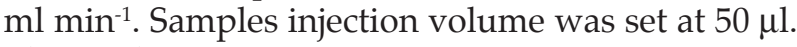
The leached metals, if any, were determined using a Varian ICP 720-ES according to JIS K 0116. The AN was analysed according to ASTM D664 using a Hiranuma Potentiometric Autotitrator COM-1700.

After $1000 \mathrm{hr}$ physical contact with test fuels, the test cup specimens were examined for any residual amount of plating using X-ray fluorescence method. Results were compared with cup specimen which was not exposed to any fuel sample. The surface morphology of terne plating on the test cups was examined and analysed using a SEM with energy dispersive X-ray spectroscopy (SEM-EDX).

\section{Analysis of Petroleum Diesel and Palm Biodiesel}

Prior to the compatibility test, the petroleum diesel and palm biodiesel were analysed for their fuel properties according to standard test methods, as in Tables 2 and 3.

\section{RESULTS AND DISCUSSION}

The properties of both the Euro $2 \mathrm{M}$ and Euro 5 petroleum diesel fuels used in this study are shown in Table 2. The significant difference between these two diesel fuels is the sulphur content. The maximum limits set are $500 \mathrm{mg} \mathrm{kg}^{-1}$ and 10 $\mathrm{mg} \mathrm{kg}^{-1}$ for the Euro 2M and Euro 5, respectively (Department of Standards Malaysia, 2014a; 2016).

TABLE 2. PROPERTIES OF EURO 2M AND EURO 5 PETROLEUM DIESEL

\begin{tabular}{|c|c|c|c|c|}
\hline Property & Test method & Unit & Euro $2 \mathrm{M}$ & Euro 5 \\
\hline ASTM colour & ASTM D1500 & - & L0.5 & L0.5 \\
\hline Ash & ASTM D482 & mass $\%$ & $<0.001$ & $<0.001$ \\
\hline Cloud point & ASTM D2500 & ${ }^{\circ} \mathrm{C}$ & -8 & -8 \\
\hline Kinematic viscosity at $40^{\circ} \mathrm{C}$ & ASTM D445 & $\mathrm{mm}^{2} \mathrm{~s}^{-1}$ & 3.7876 & 3.0138 \\
\hline Copper corrosion $\left(3 \mathrm{hr}\right.$ at $\left.50^{\circ} \mathrm{C}\right)$ & ASTM D130 & Rating & $1 \mathrm{a}$ & $1 \mathrm{a}$ \\
\hline Water & EN ISO 12937 & $\mathrm{mg} \mathrm{kg}^{-1}$ & 93 & 78 \\
\hline Sediment by extraction & ASTM D473 & mass $\%$ & $<0.01$ & $<0.01$ \\
\hline Carbon residue on $10 \%$ bottom & ASTM D189 & mass $\%$ & $<0.10$ & $<0.10$ \\
\hline Density at $15^{\circ} \mathrm{C}$ & ASTM D4052 & $\mathrm{g} \mathrm{ml}^{-1}$ & 0.8575 & 0.8371 \\
\hline Acid number & ASTM D664 & $\mathrm{mg} \mathrm{KOH} \mathrm{g}^{-1}$ & 0.03 & 0.02 \\
\hline Electrical conductivity & ASTM D2624 & $\mathrm{pS} \mathrm{m}^{-1}$ & 830 & 534 \\
\hline Derived cetane number & ASTM D6890 & - & 53.4 & 54.2 \\
\hline Lubricity & ASTM D6079 & $\mu \mathrm{m}$ & 372.5 & 402.5 \\
\hline Total sulphur & ASTM D5453 & $\mathrm{mg} \mathrm{kg}^{-1}$ & 384 & 5.1 \\
\hline
\end{tabular}

TABLE 3. PROPERTIES OF PALM BIODIESEL

\begin{tabular}{|c|c|c|c|}
\hline Property & Test method & Unit & Palm biodiesel \\
\hline Density at $15^{\circ} \mathrm{C}$ & EN ISO 12185 & $\mathrm{~kg} \mathrm{~m}^{-3}$ & 875.4 \\
\hline Kinematic viscosity at $40^{\circ} \mathrm{C}$ & EN ISO 3104 & $\mathrm{~mm}^{2} \mathrm{~s}^{-1}$ & 4.5059 \\
\hline Flash point & ASTM D93 & ${ }^{\circ} \mathrm{C}$ & 170.5 \\
\hline Water & EN ISO 12937 & $\mathrm{mg} \mathrm{kg}^{-1}$ & 306 \\
\hline Total contamination & EN 12662 & $\mathrm{mg} \mathrm{kg}^{-1}$ & $<6$ \\
\hline Copper corrosion $\left(3 \mathrm{hr}\right.$ at $\left.50^{\circ} \mathrm{C}\right)$ & EN ISO 2160 & rating & $1 \mathrm{a}$ \\
\hline Oxidation stability & EN 15751 & $\mathrm{hr}$ & 16.9 \\
\hline Acid value & EN 14104 & $\mathrm{mg} \mathrm{KOH} \mathrm{g}^{-1}$ & 0.35 \\
\hline FAME content & EN 14103 & mass $\%$ & 98.5 \\
\hline Linolenic acid methyl ester & EN 14103 & mass $\%$ & 0.2 \\
\hline Methanol & EN 14110 & mass $\%$ & $<0.01$ \\
\hline Monoglyceride & EN 14105 & $\operatorname{mass} \%$ & 0.39 \\
\hline Diglyceride & EN 14105 & mass $\%$ & 0.09 \\
\hline Triglyceride & EN 14105 & mass $\%$ & 0.02 \\
\hline Free glycerol & EN 14105 & mass $\%$ & 0.011 \\
\hline Total glycerol & EN 14105 & $\operatorname{mass} \%$ & 0.124 \\
\hline Group I metals $(\mathrm{Na}+\mathrm{K})$ & EN 14538 & $\mathrm{mg} \mathrm{kg}^{-1}$ & 4.2 \\
\hline Group II metals ( $\mathrm{Ca}+\mathrm{Mg})$ & EN 14538 & $\mathrm{mg} \mathrm{kg}^{-1}$ & $<1$ \\
\hline Phosphorus & EN 14107 & $\mathrm{mg} \mathrm{kg}^{-1}$ & $<1$ \\
\hline Sulphur & ASTM D5453 & $\mathrm{mg} \mathrm{kg} \mathrm{kg}^{-1}$ & 1.4 \\
\hline Cold filter plugging point & EN 116 & ${ }^{\circ} \mathrm{C}$ & 13 \\
\hline
\end{tabular}


The typical properties of palm biodiesel used for blending with petroleum diesel in Malaysia are shown in Table 3.

In general, palm biodiesel has lower Rancimat stability compared to petroleum diesel, as shown in Figure 1. The IP of the Euro $2 \mathrm{M}$ and Euro 5 diesel fuels measured using the Rancimat and PetroOXY methods were 7 and 2 times higher than palm biodiesel. Even without blending, the IP of palm biodiesel was $16.9 \mathrm{hr}$, which exceeds the minimum $10 \mathrm{hr}$ required by the Malaysian Standard (MS2008:2014) (Department of Standards Malaysia, 2014b). As reported previously, palm biodiesel produced from the refined, bleached and deodourised palm oil possesses superior oxidation stability. This is because the naturally inherited fatty acid compositions in the oil and its natural antioxidants remained intact even after it is processed into biodiesel (Yung et al., 2013). Blending palm biodiesel with lower oxidation stability into petroleum diesel would naturally reduce the overall stability of the blends, e.g. from the IP of $112.7 \mathrm{hr}$ down to $87.0 \mathrm{hr}$ and $78.0 \mathrm{hr}$, respectively for both the B10 and B15 of the Euro 2M diesel blends. However, these IP values were still higher than the required $20 \mathrm{hr}$ stipulated by the European Standard Specification for B10, B20 and B30 (The British Standards Institution, 2015; 2016). In pure form, Euro 5 diesel has a much lower Rancimat stability than Euro 2M diesel. Hence, the B10 and B15 of the Euro 5 diesel blends showed lower IP of 32.4 $\mathrm{hr}$ and $29.4 \mathrm{hr}$. These values had still exceeded the requirement by the European Standards but were slightly lower than the minimum $35 \mathrm{hr}$ required by the Worldwide Fuel Charter (ACEA et al., 2013).

Similar stability trends were observed for the palm biodiesel blends tested via PetroOXY. The IP of the Euro 2M B10 and Euro 5 B10 diesel blends were $239 \mathrm{~min}$ and $92 \mathrm{~min}$, i.e. 1-4 times higher than the recommended 65 min minimum limit. As shown in Figure 1, the Rancimat stability results correlated well with the PetroOXY stability results with an $\mathrm{R}^{2}$ value of 0.99 .

The concentrations of organic acids, i.e. formic acid, acetic acid and propionic acid in all the palm biodiesel blends were well below 30 ppm (Table 4 ), the maximum value specified by the Japanese Quality Assurance Law Specification. According to Tsuchiya et al. (2006), the formation of organic acids is a sign of fuel degradation and corrosion of fuel tank may occur once the value exceeds 30 ppm. The organic acids formed tend to attack the metallic components of the fuel tank and which forms metallic salts and ultimately cause adverse effects to the fuel injectors of a vehicle (Goto et al., 2010). Again, as the neat palm biodiesel was more susceptible to oxidation (with lower IP), the presence of formic acid and acetic acid becomes significant after $250 \mathrm{hr}$ storage period.
The AN of palm biodiesel blends (B7, B10 and B15) showed very minimal increase upon accelerated oxidation at $80^{\circ} \mathrm{C}$ for $1000 \mathrm{hr}$ (Table 5). This finding was similar to those reported by Kovacs et al. (2015). All the AN values of palm biodiesel blends complied with the allowable limits of 0.13 and 0.25 $\mathrm{mg} \mathrm{KOH} \mathrm{g}^{-1}$ set by both the Japanese and Malaysian Standards. Even the AN of the neat palm biodiesel after $1000 \mathrm{hr}$ storage was below the limit of $0.5 \mathrm{mg}$ $\mathrm{KOH} \mathrm{g}^{-1}$.

The appearances of test cups after $1000 \mathrm{hr}$ with direct exposure to test fuels are shown in Figures 2 and 3. Optical observations showed no physical trace of corrosion for all the specimens inspected, including cup specimens exposed to the neat palm biodiesel. The X-ray fluorescence results (Table 6) concurred with the optical inspection. The amount of terne plating for cup specimens exposed to all the palm biodiesel blends was quite similar, $40 \mathrm{~g} \mathrm{~m}^{-2}$ on average. In addition, Table 7 showed that there were hardly any leached metals into the palm biodiesel blends at storage at $80^{\circ} \mathrm{C}$. The SEM-EDX analysis showed that only lead and tin were detected on the surface of all the cup specimens. There were no significant differences among all the cup specimens directly in contact with the neat diesel, palm biodiesel and its blends, with the blank cup (Figures 4 and 5). All the SEM images showed equal plating surfaces without corrosion or pitting. This showed that there was hardly any terne plating deterioration in the test cups during storage, and thus the palm biodiesel blends behaved similarly to the blank cup without exposure to any diesel fuel and those filled with neat palm biodiesel. These results were distinctively different from those obtained previously by Tsuchiya et al. (2006) and JPEC (2012), which mainly attributed to the different sources of biodiesel and petroleum diesel used. In this study, the commercial palm biodiesel used had Rancimat stability exceeded $10 \mathrm{hr}$ whereas JPEC (2012) used less stable soyabean oil biodiesel. On top of that, the commercial petroleum diesel, i.e. Euro $2 \mathrm{M}$ and Euro 5 used were also much superior compared to the less stable ones used in other studies.

\section{CONCLUSION}

This study showed that palm biodiesel and its blends with petroleum diesel (B7, B10 and B15) possessed superior oxidation stability. Inspection and observation on the side walls of the test cups exposed to palm biodiesel and its blends at elevated temperature $\left(80^{\circ} \mathrm{C}\right)$ showed no corrosion and pitting. The tested terne sheet was highly compatible with the neat palm biodiesel and its blends with petroleum diesel up to $15 \mathrm{vol} \%$. The terne sheet was found compatible with palm biodiesel blends as long as the test fuels in use were of good quality. 


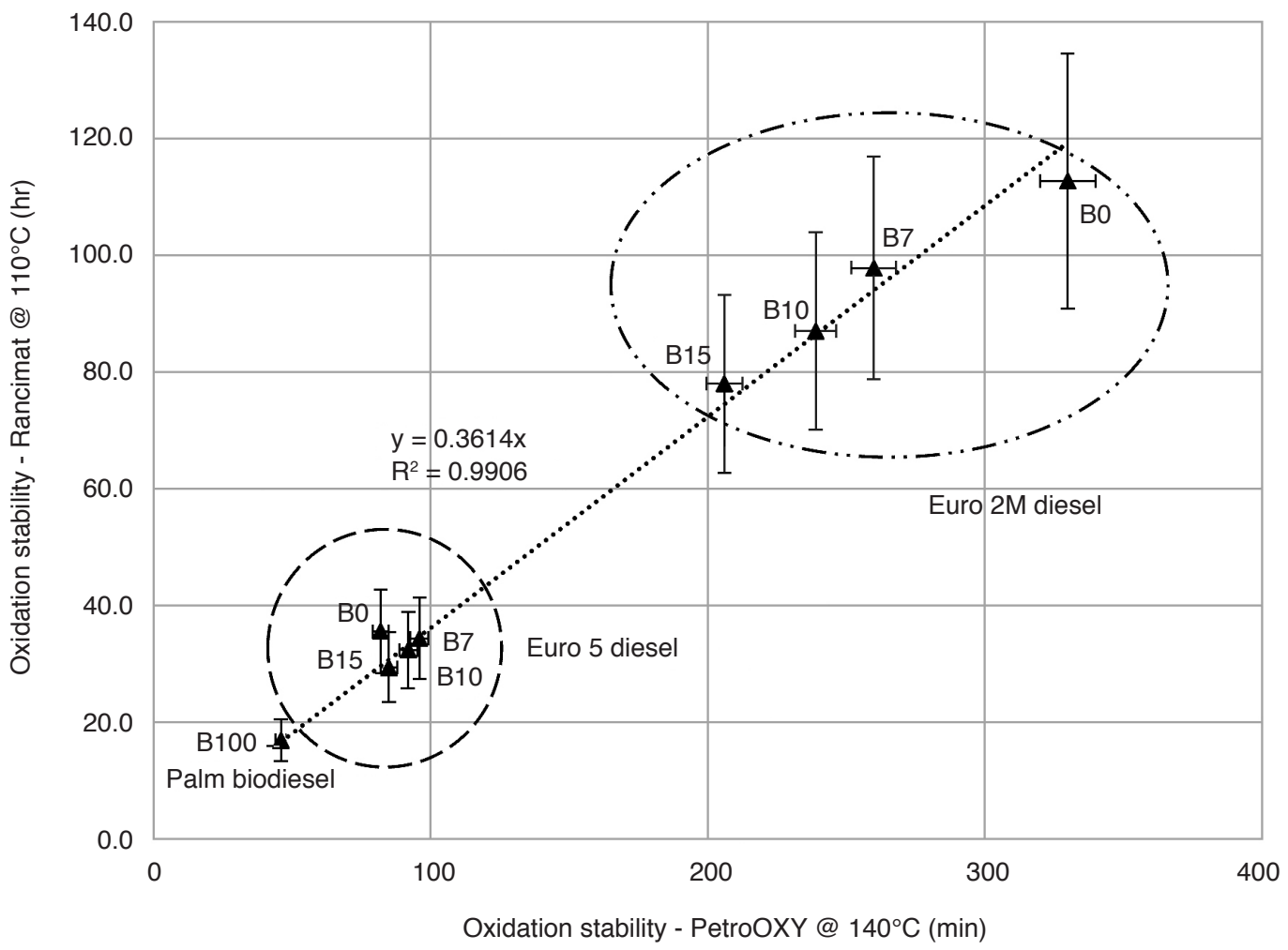

Figure 1. The induction periods of palm biodiesel blends via the Rancimat and PetroOXY tests. $R=0.37269+0.19038 X$ for Rancimat. $R=0.0863 X+1.3772$ for PetroOXY.

TABLE 4. ORGANIC ACIDS CONTENTS OF PALM BIODIESEL BLENDS AFTER THE TERNE CUP TEST AT ELEVATED TEMPERATURE $\left(80^{\circ} \mathrm{C}\right)$

\begin{tabular}{|c|c|c|c|c|c|c|c|c|c|}
\hline \multirow[t]{2}{*}{ Fuel } & \multicolumn{3}{|c|}{ Formic acid (ppm) } & \multicolumn{3}{|c|}{ Acetic acid (ppm) } & \multicolumn{3}{|c|}{ Propionic acid (ppm) } \\
\hline & $0 \mathrm{hr}$ & $250 \mathrm{hr}$ & $1000 \mathrm{hr}$ & $0 \mathrm{hr}$ & $250 \mathrm{hr}$ & $1000 \mathrm{hr}$ & $0 \mathrm{hr}$ & $250 \mathrm{hr}$ & $1000 \mathrm{hr}$ \\
\hline Euro 2M diesel (B0) & 0.8 & 1.3 & 1.2 & $<0.3$ & 2.1 & 1.3 & $<0.3$ & 0.3 & $<0.3$ \\
\hline Euro 2M B7 & 1.0 & 1.4 & 1.4 & 0.5 & 3.3 & 2.2 & $<0.3$ & 0.4 & $<0.3$ \\
\hline Euro 2M B10 & 1.2 & 1.6 & 1.5 & 0.7 & 1.8 & 1.9 & $<0.3$ & $<0.3$ & 0.3 \\
\hline Euro 2M B15 & 0.9 & 3.3 & 1.8 & 0.6 & 4.0 & 2.9 & $<0.3$ & 0.6 & 0.5 \\
\hline Euro 5 diesel (B0) & 0.8 & 1.6 & 1.1 & $<0.3$ & 2.1 & 0.5 & $<0.3$ & 0.3 & $<0.3$ \\
\hline Euro 5 B7 & 1.0 & 1.4 & 1.5 & 0.5 & 1.4 & 0.9 & $<0.3$ & $<0.3$ & $<0.3$ \\
\hline Euro 5 B10 & 1.2 & 1.7 & 1.8 & 0.5 & 2.5 & 2.1 & $<0.3$ & 0.6 & 0.3 \\
\hline Euro 5 B15 & 1.2 & 2.3 & 3.6 & 0.6 & 7.6 & 4.9 & $<0.3$ & 0.7 & 0.5 \\
\hline Palm biodiesel (B100) & 2.2 & 7.2 & 19.0 & 1.9 & 35.0 & 54.0 & 0.3 & 1.1 & 1.4 \\
\hline
\end{tabular}

TABLE 5. ACID NUMBERS (AN) OF PALM BIODIESEL BLENDS AFTER THE TERNE CUP TEST AT ELEVATED TEMPERATURE $\left(80^{\circ} \mathrm{C}\right)$

\begin{tabular}{lccccc}
\hline & \multicolumn{5}{c}{ Storage period (hr) } \\
\cline { 2 - 6 } Fuel & $\mathbf{0}$ & $\mathbf{2 5 0}$ & $\mathbf{5 0 0}$ & $\mathbf{7 5 0}$ & $\mathbf{1 0 0 0}$ \\
\hline Euro 2M diesel (B0) & 0.03 & 0.04 & 0.02 & 0.04 & 0.03 \\
Euro 2M B7 & 0.05 & 0.05 & 0.06 & 0.06 & 0.06 \\
Euro 2M B10 & 0.06 & 0.06 & 0.07 & 0.07 & 0.07 \\
Euro 2M B15 & 0.08 & 0.09 & 0.08 & 0.09 & 0.09 \\
Euro 5 diesel (B0) & 0.02 & 0.03 & 0.02 & 0.02 & 0.02 \\
Euro 5 B7 & 0.04 & 0.03 & 0.04 & 0.04 & 0.03 \\
Euro 5 B10 & 0.05 & 0.05 & 0.05 & 0.05 & 0.05 \\
Euro 5 B15 & 0.06 & 0.07 & 0.07 & 0.06 & 0.06 \\
Palm biodiesel (B100) & 0.35 & 0.42 & 0.44 & 0.46 & 0.45 \\
\hline
\end{tabular}

TABLE 6. THE AMOUNT OF TERNE PLATING OF SPECIMENS AFTER THE TERNE CUP TEST AT ELEVATED TEMPERATURE $\left(80^{\circ} \mathrm{C}\right)$

Fuel Residual amount
of plating $\left(\mathrm{g} \mathrm{m}^{-2}\right)$

Euro 2M diesel (B0)

40
40
45
42
46
42
45
41
43
42




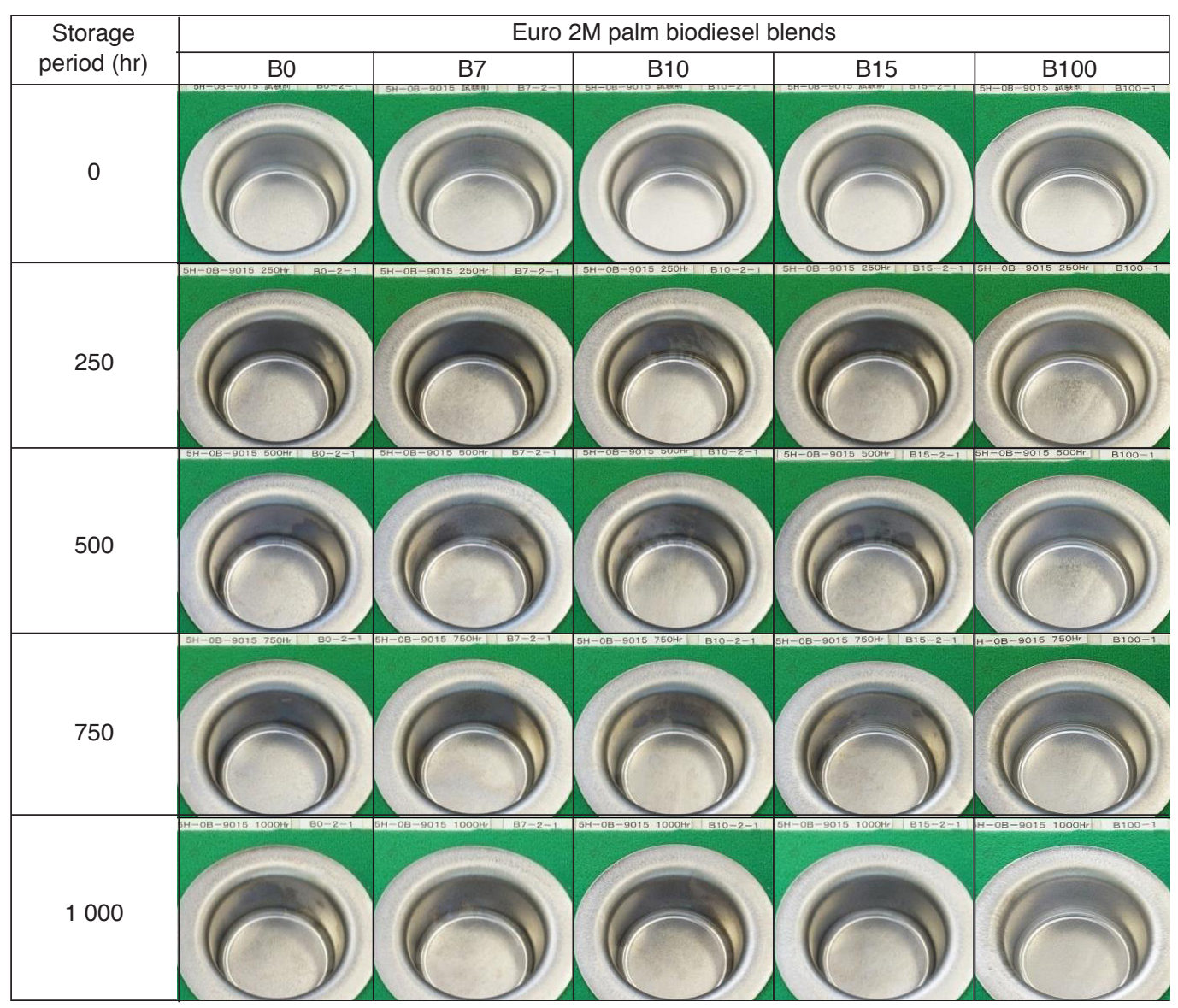

Figure 2. Appearances of test cups after exposed to Euro 2M palm biodiesel blends.

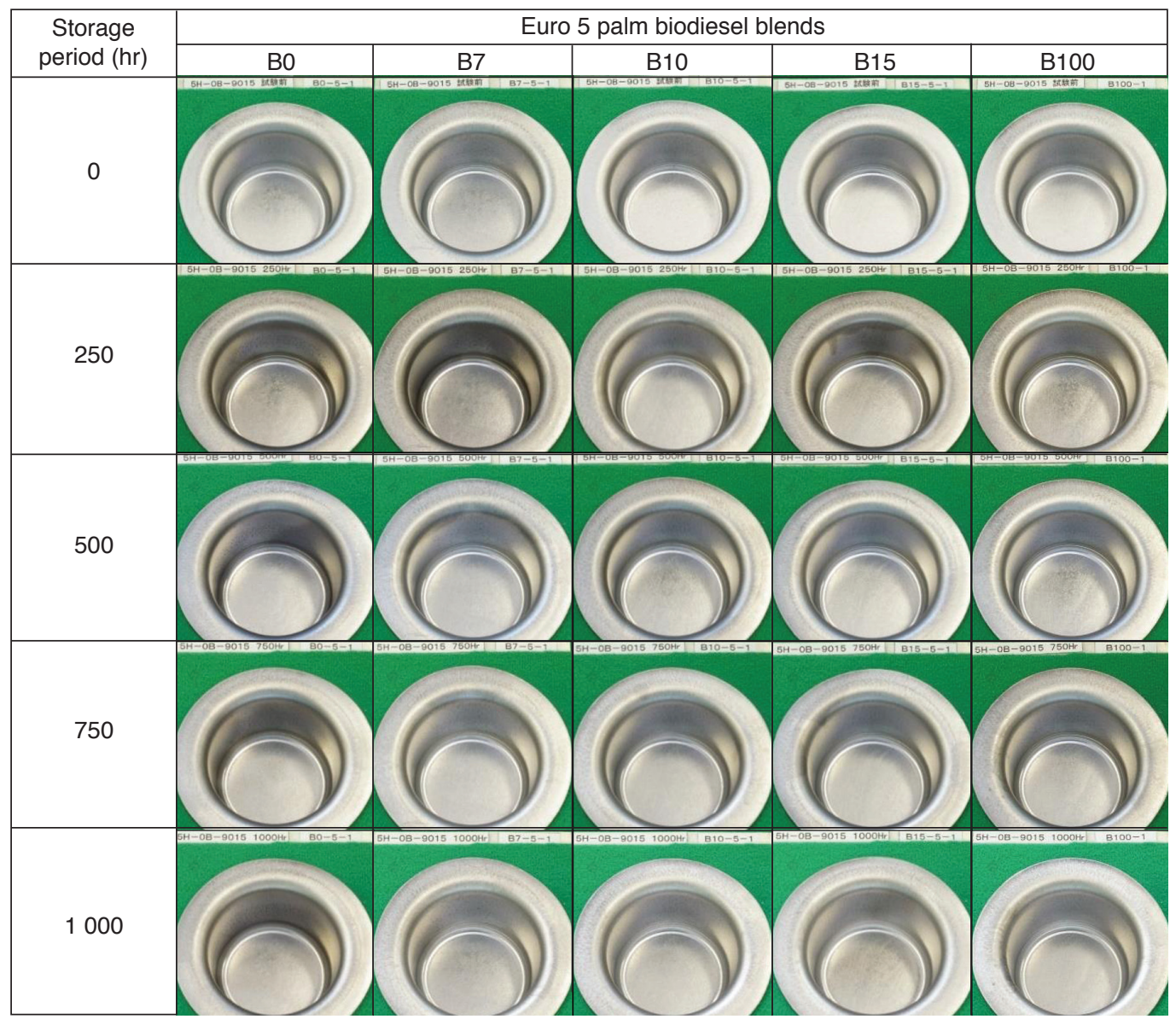

Figure 3. Appearances of test cups after exposed to Euro 5 palm biodiesel blends. 


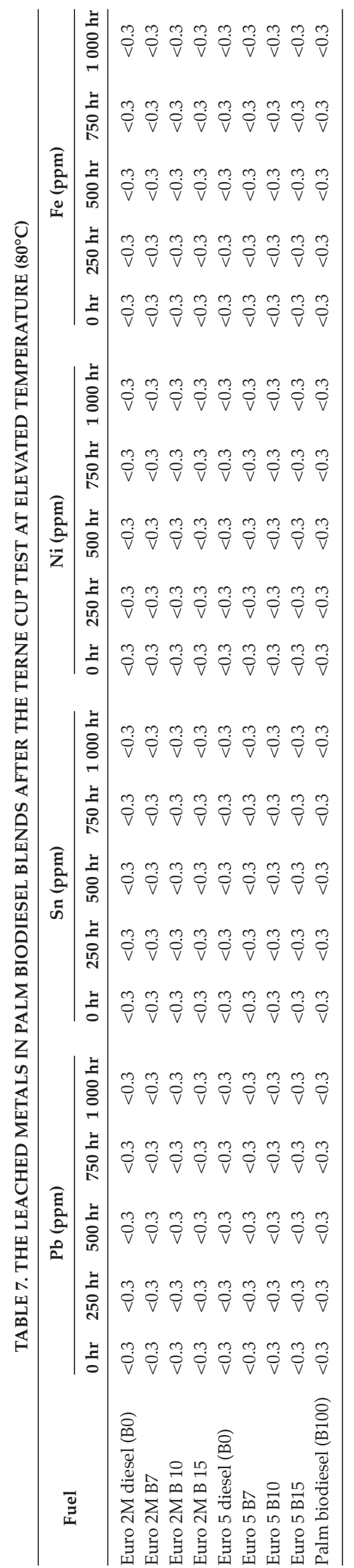

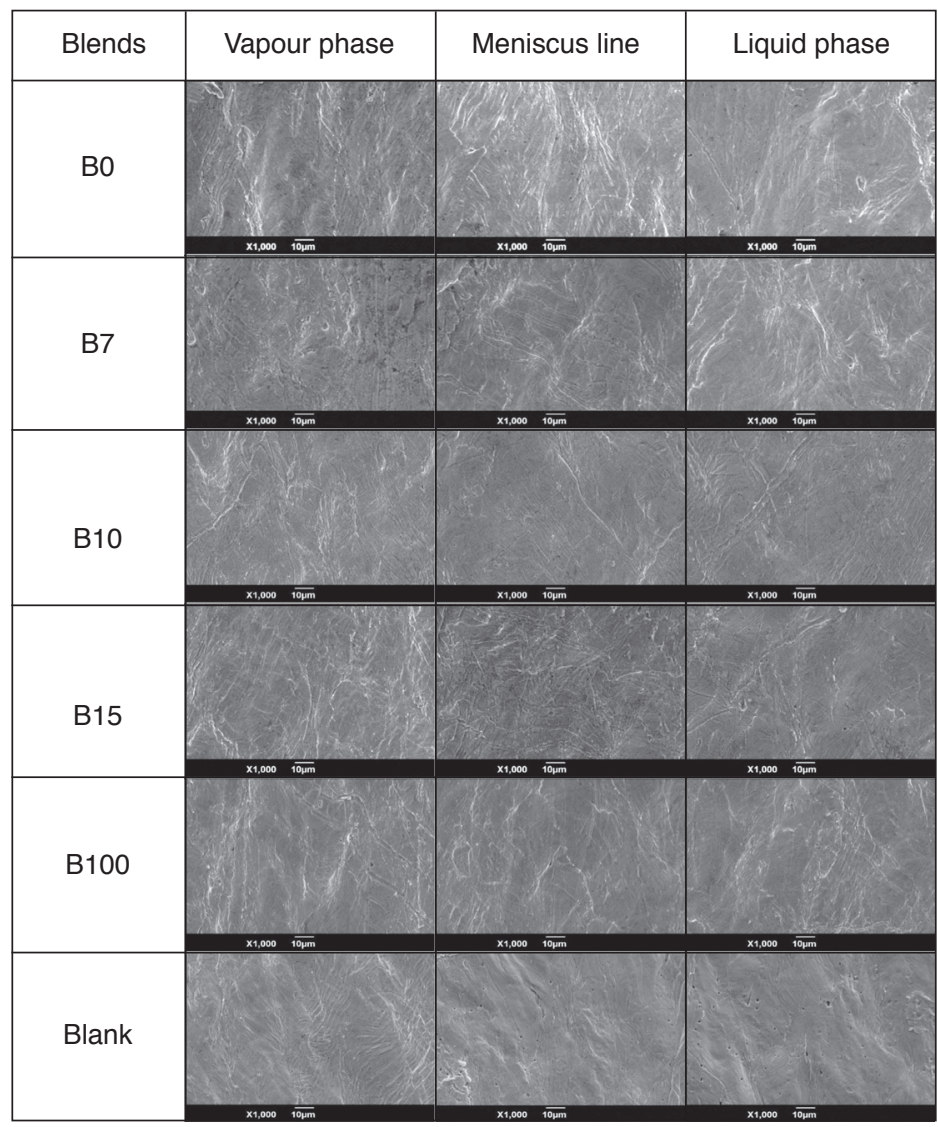

Figure 4. Scanning electron microscopy (SEM) images showing plating surfaces of test cups after exposed to Euro $2 \mathrm{M}$ palm biodiesel blends.

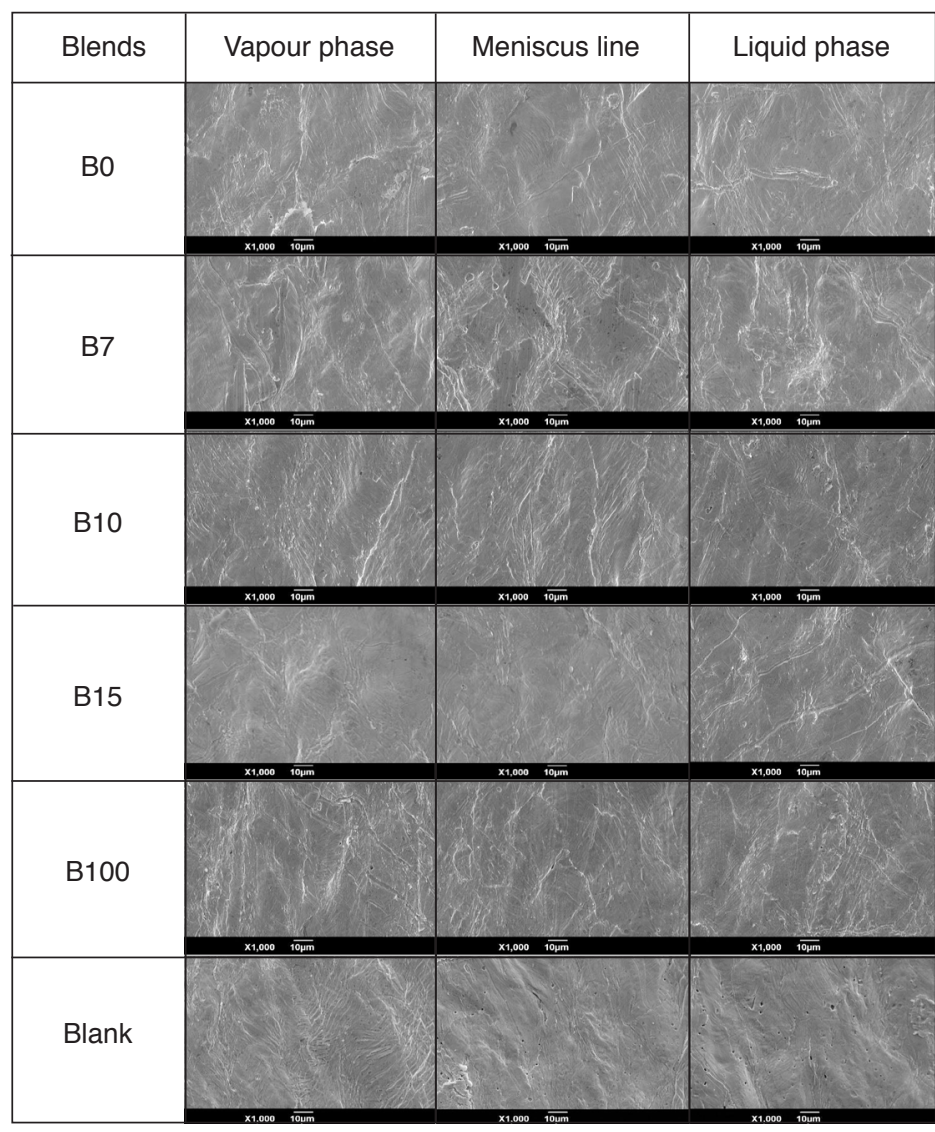

Figure 5. Scanning electron microscopy (SEM) images showing plating surfaces of test cups after exposed to Euro 5 palm biodiesel blends. 


\section{ACKNOWLEDGEMENT}

The authors thank the Director-General of MPOB for permission to publish this article. Appreciations are also due to Tomoaki Kakihara, Japanese Automobile Manufacturers' Association and members of Biodiesel Working Group, MPOB for the discussion and suggestions made in conducting this study.

\section{REFERENCES}

ACEA; AUTO ALLIANCE; EMA and JAMA (2013). Worldwide Fuel Charter. $5^{\text {th }}$ edition. http://www. acea.be / uploads / publications / Worldwide_Fuel_ Charter_5ed_2013.pdf

ALI, Y; HANNA, M A and CUPPETT, S L (1995). Fuel properties of tallow and soybean oil esters. J. Amer. Oil Chem. Soc. Vol. 72: 1557-1564.

ALLEMAN, T L; FOUTS, L and MCCORMICK, R L (2011). Quality analysis of wintertime B6-B20 biodiesel blend samples collected in the United States. Fuel Processing Tech., 92: 1297-1304.

ASTM INTERNATIONAL (2015). ASTM D6751 Standard Specification for Biodiesel Fuel Blend Stock (B100) for Middle Distillate Fuels. ASTM International, West Conshohocken.

CHANG, D Y Z; VAN GERPEN, J H; LEE, I and JOHNSON, L A (1996). Fuel properties and emissions of soybean oil esters as diesel fuel. J. Amer. Oil Chem. Soc. Vol. 73: 1549-1555.

CHOO, Y M; MA, A N and BASIRON, Y (1995). Production and evaluation of palm oil methyl esters as diesel substitute. J. Oil Palm Res. Special Issue: 5-25.

CLARK, S J; WAGNER, L; SCHROCK, $\mathrm{M}$ and PIENNAAR, P G (1984). Methyl and ethyl soybean esters as renewable fuels for diesel engines. J. Amer. Oil Chem. Soc. Vol. 10: 1632-1638.

CVENGROS, J; PAVLOVICOVA, A; GLADISOVA, G and CERNY, J (1999). Rapeseed oil methyl esters with low phosphorus content. Fett/Lipid, 101: 261265.

DEPARTMENT OF STANDARDS MALAYSIA (2014a). MS123-1 Malaysian Standard Specification for Diesel. Part 1: Euro 2M. Fourth revision. Department of Standards Malaysia, Cyberjaya.

DEPARTMENT OF STANDARDS MALAYSIA (2014b). MS2008 Malaysian Standard Specification for Automotive Fuels - Palm Methyl Ester (PME) for Diesel
Engines - Requirement and Test Methods. Department of Standards Malaysia, Cyberjaya.

DEPARTMENT OF STANDARDS MALAYSIA (2016). MS123-3 Malaysian Standard Specification for Diesel. Part 3: Euro 5. Department of Standards Malaysia, Cyberjaya.

FAZAL, M A; HASEEB, A S M A and MASJUKI, H $H$ (2010). Comparative corrosive characteristics of petroleum diesel and palm biodiesel for automotive materials. Fuel Processing Tech., 91: 1308-1315.

FAZAL, M A; HASEEB, A S M A and MASJUKI, H $H$ (2011a). Effect of different corrosion inhibitors on the corrosion of cast iron in palm biodiesel. Fuel Processing Tech., 92: 2154-2159.

FAZAL, M A; HASEEB, A S M A and MASJUKI, H $H$ (2011b). Effect of temperature on the corrosion behavior of mild steel upon exposure to palm biodiesel. Energy, 36: 3328-3334.

FAZAL, M A; HASEEB, AS M A and MASJUKI, H H (2012). Degradation of automotive materials in palm biodiesel. Energy, 40: 76-83.

GOTO, S; OGUMA, Mand CHOLLACOOP, N (2010). Benchmarking of biodiesel fuel standardization in East Asia working group. EAS-ERIA Biodiesel Fuel Trade Handbook. http:/ / www.eria.org/EAS-ERIA_ Biodiesel\%20Fuel\%20Trade_Handbook_2010.pdf p. 27-62.

GUZMAN, R C; TANG, H; WADUMESTHRIGE, S; ZHOU, T; GARCIA-PEREZ, M D and NG, K Y S (2010). Quality survey of retail biodiesel blends in Michigan. Fuel, 89: 3662-3667.

HASEEB, A S M A; MASJUKI, H H; ANN, L J and FAZAL, M A (2010). Corrosion characteristics of copper and leaded bronze in palm biodiesel. Fuel Processing Tech., 91: 329-334.

HU, E; XU, Y; HU, X; PAN, L and JIANG, S (2012). Corrosion behaviors of metals in biodiesel from rapeseed oil and methanol. Renewable Energy, 37: 371-378.

JAPAN PETROLEUM ENERGY CENTER (JPEC) (2012). Study on biofuels utilization in diesel vehicles. JATOP Technical Report 2012 JPEC-2011JP-01.

KAUL, S; SAXENA, R C; KUMAR, A; NEGI, M S; BHATNAGAR, A K; GOYAL, H B and GUPTA, A $K$ (2007). Corrosion behavior of biodiesel from seed oils of Indian origin on diesel engine parts. Fuel Processing Tech., 88: 303-307. 
KOVACS, A; TOTH, J; ISAAK, $\mathrm{G}$ and KARESZTENYI, I (2015). Aspects of storage and corrosion characteristics of biodiesel. Fuel Processing Tech., 134: 59-64.

KUSHAIRI, A; SNGH, R and ONG-ABDULLAH, $M$ (2017). The oil palm industry: Thriving with transformative technologies. J. Oil Palm Res. Vol. 29(4): 431-439.

MITTELBACH, M and ENZELSBERGER, H (1999). Transesterification of heated rapeseed oil for extending diesel fuel. J. Amer. Oil Chem. Soc. Vol. 76: $545-550$

TANG, H; ABUNASSER, N; WANG, A; CLARK, B R; WADUMESTHRIGE, $\mathrm{K}$ and ZENG, S (2008). Quality survey of biodiesel blends sold at retail stations. Fuel, 87: 2951-2955.

THE BRITISH STANDARDS INSTITUTION (BSI) (2015). BS EN 16709 Automotive Fuels - High FAME
Diesel Fuel (B20 and B30) - Requirements and Test Methods. BSI, London.

THE BRITISH STANDARDS INSTITUTION (BSI) (2016). BS EN 16734 Automotive Fuels - Automotive B10 Diesel Fuel - Requirements and Test Methods. BSI, London.

TSUCHIYA, T;SHIOTANI,H; GOTO, S; SUGIYAMA, G and MAEDA, A (2006). Japanese Standards for diesel fuel containing 5\% FAME: Investigation of acid generation in FAME blended diesel fuels and its impact on corrosion. SAE Tech Paper No. 2006-013303.

YUNG, C L; LAU, H L N and CHOO, Y M (2013). Physico-chemical properties of biodiesel produced from Jatropha curcas oil and palm oil. J. Oil Palm Res. Vol. 25: 159-164.

YUNG, C L; LOH, S K, LIM, W S and CHOO, Y M (2016). Malaysian B5 implementation and its quality. J. Oil Palm Res. Vol. 28: 331-343. 